Advances in Geosciences, 6, 221-225, 2006

SRef-ID: 1680-7359/adgeo/2006-6-221

European Geosciences Union

(c) 2006 Author(s). This work is licensed

under a Creative Commons License.

\title{
The Impact of El Niño - Southern Oscillation Events on South America
}

\author{
J. L. Santos \\ Escuela Superior Politécnica del Litoral. Guayaquil, Ecuador
}

Received: 20 January 2006 - Revised: 5 February 2006 - Accepted: 6 February 2006 - Published: 17 February 2006

\begin{abstract}
The presence of ENSO Events in South America is felt in two ways: a) through its effects on both the atmosphere and ocean systems, and b) through its impacts on natural ecosystems (both marine and terrestrial) and on societal and economical sectors (like fisheries, health, and agriculture).

The main effects of El Niño/La Niña are: Increment/Decrement of sea surface temperature and salinity, Increment/Decrement of sea level and wave activity, Increment/Decrement of air temperature and amount of ultra violet radiation reaching the surface of the earth, and Changes in the rainfall and evaporation patterns.

It is not easy to make an "average" pattern of ENSO impacts for a variety of reasons: the impacts depend greatly of factors like geographical extent and position of the oceanic anomalies, and intensity and timing of the anomalies; also the influence of social, economic and political structures determines whether climate anomalies caused by ENSO in a particular region will lead to severe societal and economical impacts.

The scientific community also plays a potential role in the extent of the impacts that ENSO can produce, if scientists can provide information on the impact of the presence of ENSO by identifying and focusing on its precursors, intervention could be taken early enough. There is however, something to be said against that: information can be misleading, target inappropriate at-risk groups, or generate a false sense of security.
\end{abstract}

\section{Introduction}

El Niño Phenomenon is a recurrent, quasi-periodic appearance of warm sea surface water in the central equatorial Pacific Ocean generated by ocean-atmosphere interactions internal to the tropical Pacific and overlying atmosphere, this anomaly can sometimes reverse and lead to the presence of cold waters in the aforementioned region, thus the term El Niño - Southern Oscillation (ENSO) is widely used to refer to this oceanic-atmospheric seesaw. ENSO is recognized as the largest mode of interannual variability of the global climate system, with a recurrence period around the $2-8$ year band (Santos, 1999).

There are several reasons why we focus on ENSO, these include: El Niño represents a climate signal with a high degree of predictability, monitoring and forecasts provide enough lead time to effectively act in some places/countries, real-time monitoring of El Niño's evolution has greatly improved (e.g., TAO Array and Argo floats); and finally, ENSO is known to be a hazard-spawner in many locations around the globe causing tremendous negative socioeconomic impacts specially in developing countries.

Despite the potential value of ENSO information to societies around the globe, the scientific community has often underestimated the importance of research on the societal aspects of El Niño events, including how best to use El Niño forecast information to provide socially and economically useful research climate predictions to its members in order to reduce the negative impacts and take advantage of the positive impacts that the presence of ENSO events produces. 


\section{Impacts of ENSO}

The presence of ENSO Events in South America is felt in two ways: a) trough its effects on the atmosphere and ocean systems, and b) trough its impacts on natural ecosystems (both marine and terrestrial) and on socio-economic sectors (like fisheries, health, and agriculture).

The main effects of El Niño/La Niña are:

- Increment/Decrement of sea surface temperature and salinity

- Increment/Decrement of sea level and wave activity

- Increment/Decrement of air temperature and amount of ultra violet radiation reaching the surface of the earth

- Changes in the rainfall and evaporation patterns

Through a series of geological, oceanographic, hydrologic, geochemical, biological, archeological and historic records, the presence of ENSO Events in South America has been traced back to several centuries (Machare and Ortlieb, 1993). The effects that these events have produced on the climate in this region have been widely document in several works, for a recent summary, see WMO (2003).

The significant deviations in the climatological patterns (especially of air temperature and precipitation) caused by ENSO are responsible for social and economic impacts that can be of great magnitude, depending on the intensity and timing of such deviations.

The changes in precipitation patterns, causing a direct influence in River flow in Argentina Paraguay, Brazil, Paraguay, Chile, Colombia, Ecuador, Mexico, Panama, Peru, and Venezuela have been documented by Berri (1995).

Regarding the impacts on biological ecosystems; Barber (1983) indicated that nutrients, phytoplankton biomass, and primary productivity are clearly regulated by the physical changes on ENSO; evidence also suggest effects on higher organisms such as fish, seabirds and marine mammals, but more observations are required to accurately determine the magnitude of the consequences on these higher trophic levels.

Until now many people think that ENSO impacts are restricted to marine ecosystem; however, great impacts in terrestrial ecosystems have been documented as well, (see Holmgren et al., 2006). Another very frequent misconception is to consider that only the warm phase (El Niño) is capable of having positive or negative biological impacts upon the resources; however there are also clear signs of a cold phase (La Niña) impact. It was common to think before El Niño of 1982-1983 that ENSO events only had negative effects. Research, especially in marine shallow depths, has shown positive impacts as well (Tarazona, 1999).

On the other hand, research in recent years has demonstrated that ENSO impacts not only affect the species level of both the marine and the terrestrial environments, but also influences cell, individual, population, community, and ecosystem levels. A lot of data on this subject has been complied trough a regional effort which is called the RIBEN (Network of Biological Impacts caused by El Niño), see: http://www. concytec.gob.pe/investigacion/biologia/riben/iriben.htm.

Fisheries in the Humboldt current represent the largest in the world not only if one considers the primary production and catch potential of its waters but also in view of its recordsetting catches, this invaluable marine ecosystem has been constantly beset by oceanic-climatic oscillations caused by ENSO, (Caviedes, 1992). Other researchers have carried on regional studies on the effects of ENSO on the upwelling and oceanic currents, biology and fisheries, (Flores, 1989; Avaria et al., 2004).

Based on the World Health Organization definition of health as "... a state of complete physical, mental and social well-being and not merely the absence of disease or infirmity...." several possible impacts of ENSO have been documented (i.e. Balbus and Wilson, 2001; WHO, 2003; Patz, 1996). These studies show that climatic factors influence the emergence and reemergence of infectious diseases, in addition to multiple human, biological and ecological determinants. The incidence of mosquito-borne diseases, including malaria, dengue, and viral encephalitides, have been directly correlated to the presence of ENSO in countries like Argentina, Colombia, Ecuador, Peru and Brazil.

Regarding agriculture in the Andean Region, it has been affected by ENSO in three main areas: a) production and productivity, b) availability of production for exports, and c) physical infrastructure. The severity of the effects varies depending of each country and region, it is also important to point out that although to a lesser extent, several positive effects have been documented in countries like Bolivia, Venezuela and Chile, (Meek and Aldana, 1998; WMO, 2004)

The Food and Agriculture Organization of the United Nations (FAO, 2005), regularly makes assessments of crop production in Latin America, these assessments respond almost immediately to the presence of ENSO, but they depend greatly on factors like geographical extent and position of the oceanic anomalies, and intensity and timing of the anomalies (see: http://www.fao.org/giews/english/index.htm).

For this reason, it is very difficult to try to make a general pattern of influences in agriculture caused by the presence of ENSO, however in general; in the southern areas of South America, heavy rains hamper harvesting of cereal crops as wheat, both in output and quality. By contrast abundant rains might benefit the development of crops like maize.

But it is when we take a look at the socio-economic impacts that we realize the magnitude of the influence that the presence of ENSO can produce in our lives. Two comprehensive studies have been carried out on the effects caused by the two strongest events in the last century (1982-1983 and 1997-1998) in South America, (CEPAL, 1998; and CAF, 2000); these works make Sectoral assessment of impacts, rehabilitation and reconstruction.

Tables 1 and 2, present some figures that give an idea of the economic impacts on several countries in South America due to the 1997-1998 event, which amounts to several percentile points of the GIP (up to 5\% in some cases), however they fail 
Table 1. Direct and Indirect damaged caused by the El Niño Event of 1997-1998 (by country, in millions of dollars). TOTAL: \$7.544 (CAF, 2.000).

\begin{tabular}{lccccc}
\hline Damage & Venezuela & Colombia & Bolivia & Ecuador & Peru \\
\hline Lost of Production & 32.7 & 148.1 & 263.3 & 1.421 & 1.093 \\
Greater costs of operation & 26.6 & 311.1 & 24.9 & 836 & 391 \\
Prevention, Emergency & 9.3 & 50.6 & 12.3 & 331 & 405 \\
Heap Losses & 2.6 & 52.8 & 226.8 & 294 & 1.612 \\
\hline
\end{tabular}

to show the extent of social impacts reflected in the thousands of human lives lost, and the tens of thousands that lost their homes. These figures clearly show the high vulnerability of certain areas in South America to the presence of ENSO, a vulnerability that in general has steadily increased in the last 10 years due to the way this region is developing.

\section{The impact of information}

Experience has shown that several of the impacts described in the previous paragraphs can be greatly mitigated; a judicious use of El Niño forecast information could provide considerable lead time for agencies to prepare for likely problems, several successful cases can be found (Santos, 2004).

ENSO and climate information can be used as tools in the decision making process because there is plenty of information about impacts on several socioeconomic sectors, and also a multidisciplinary approach can be used to provide scenarios under different types of events. We need to keep in mind that scientists need to tailor climate information for policy and decision-makers; some efforts in different parts of the world have given positive results. There are also plenty of opportunities in what is called "El Niño engineering": establishment of construction regulations and development and use of new standards to avoid future problems.

In dealing with ENSO, we face several problems in impact mitigation and prevention: at the moment it is unknown (or very difficult to estimate with high degree of certainty) the duration and magnitude of an event. In several parts of the world (especially in developing countries) there is lack of credibility due to a lack of climate culture. Also in these less developed countries there is often lack of organization and funds, political problems, confusion in how the information is distributed, and poor planning that produces frequent and often unpredictable land use cover and change

El Niño became a worldwide issue during its occurrence in the 1982-1983 period, after which a lot of research and monitoring, leading to improvement on its knowledge has been achieved, which accounted for the fact that several parts of the world were better prepared for the next big ENSO fifteen years later thanks to the implementation of effective early warning systems. Thus, some success stories can be identified from the El Niño 1997-1998 like effective mitigation, in northern Peru; lesser losses in the aquaculture in coastal
Table 2. Direct and Indirect damaged cause by the El Niño Event of 1997-1998 (by sector, in millions of dollars). TOTAL: $\$ 7.544$ (CAF, 2.000).

\begin{tabular}{lccccc}
\hline Sector & Venezuela & Colombia & Bolivia & Ecuador & Peru \\
\hline Productive & 38.5 & 148.6 & 261.6 & 1.516 & 1.627 \\
Transport & 2.3 & & 237.7 & 795 & 717 \\
Forest Fires & 2.6 & 52.3 & & & \\
Social & & 40.9 & 5.3 & 205 & 485 \\
Services & 27.8 & 309.5 & 10.4 & 36 & 237 \\
Others & & 12.2 & 12.3 & 331 & 434 \\
\hline
\end{tabular}

Ecuador; more effective prevention of Malaria outbreaks in Colombia; improved water management in Panama among others. However those were rather isolated cases and in general the 1997-1998 strong ENSO event caused even more socioeconomic damage that its predecessor. Economic losses were in the order of several billions of dollars, and tens of thousands of human lives were lost. Even now, some countries have not yet fully recovered from the impact caused by the El Niño of 1997-1998.

There is a recent lesson learned regarding the impact of information and how we can prepare for the occurrence of ENSO, and is what happened in Ecuador, South America during the 2002-2003 weak event. In 11 July 2002 the NOAA web page published the following message: “.... It's now official, El Niño is back. It's not the powerful, climatic juggernaut of 1997-1998, but a milder, weaker version that may begin affecting weather in the United States by fall 2002, according to NOAA's National Weather Service. The agency's climate experts today said mature El Niño conditions likely will develop in a few months...." (NOAA, 2002).

The message was very clear and accurate but it got in the wrong hands: the next few days newspapers in the two major cities of Ecuador announced that El Niño was already present. This created panic among many sectors, probably the sector most concerned was the agricultural sector, since most of the crops in Ecuador are rain fed. But the heavy precipitation rates that are expected in Ecuador during an El Niño event never came, what is even worse not only that the rains did not start around July or August but the onset of the normal rainy season that usually starts by the end of 


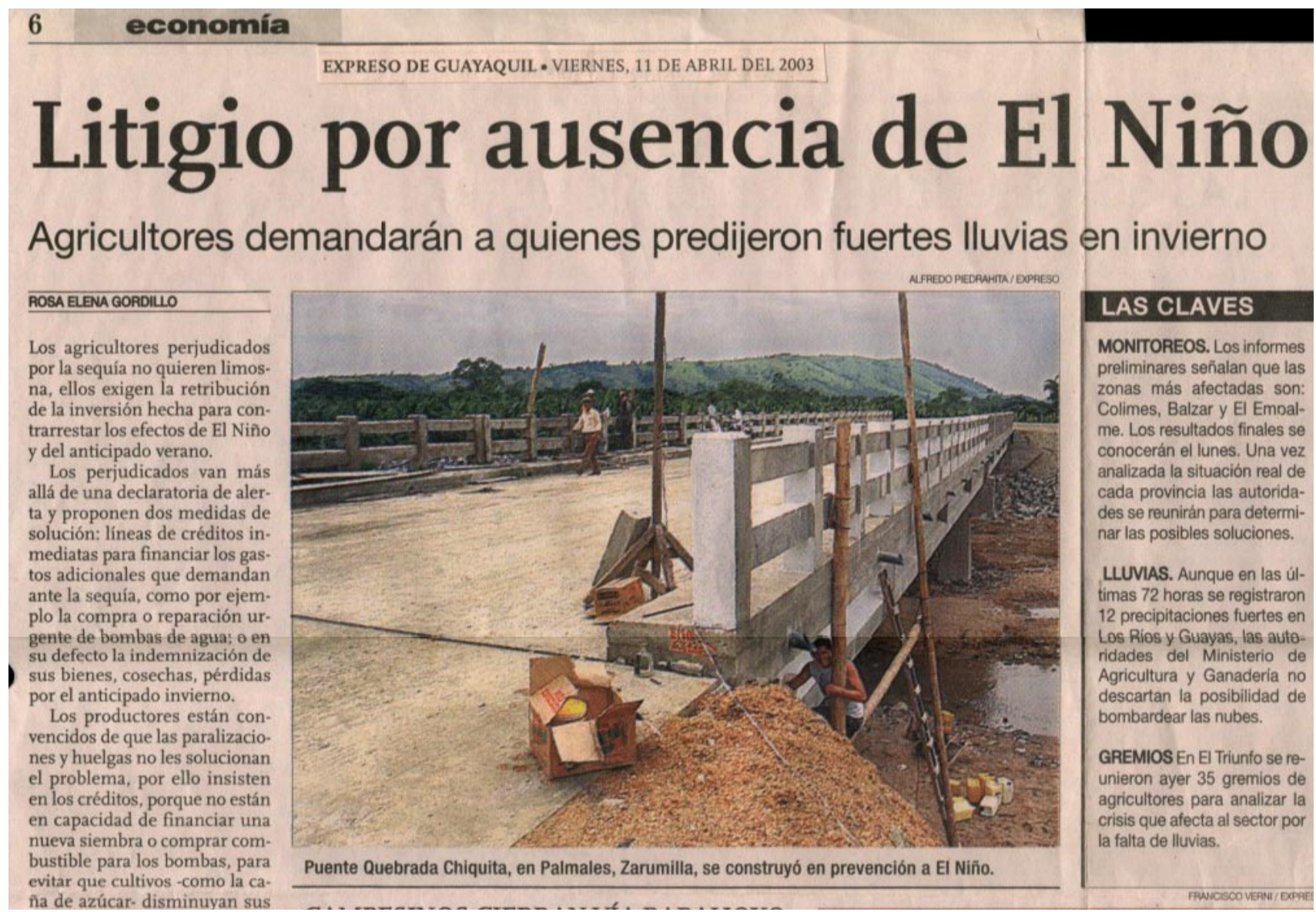

Fig. 1. Headline of a Guayaquil Newspaper: "Litigation because the absence of El Niño. Farmers will sue those who predicted rains" (Expreso, 2003).

December was delayed by several weeks. The result was extensive agricultural losses and frustration from the farmer community that reached to a point in which they threatened to sue the local technical institutions for the "wrong" forecast (see Fig. 1).

In this figure one can also see the picture of a brand new bridge, constructed in a couple of months in preparation for an increase in river flow which never happened, resources that could certainly have been better allocated. This experience illustrates the point that usually, the fastest the response to what is perceived as an emergency, the least likely that these responses are based in methodologies that contribute to sustain development processes.

\section{Discussion}

Today, early warning systems draw considerable attention worldwide. Interest in such systems is based on the belief that, if one could forecast the emergence of a certain negative impact in a sector of socio economical importance, by identifying and focusing on its precursors, intervention could be taken early enough. There is however, something to be said against them: They can be misleading, target inappropriate at-risk groups, or generate a false sense of security. There is also a point that should be considered: Is the real problem a lack of detail information? Or should we be using the existing information more effectively?

We also have to keep in mind the influence of social, economic and political structures in determining whether climate anomalies caused by ENSO in a particular region will lead to severe societal and economical impacts.

The conclusion that nonphysical factors may determine whether the potential problems caused by climate anomalies associated to ENSO will be realized in a specific country or at a specific time does not, however, invalidate the point that increased climate variability associated with ENSO heightens the potential for severe societal impacts.

If the research community is to play a greater role in reducing the impacts of ENSO events, there are some key points that should be kept in mind:

- We need to improve the communication between scientists and end-users. It is important that there is continuous feedback from the end-user community in order to 
make the climate forecasts more relevant and applicable to important socio-economic areas.

- Delivering of specific products (according to sector and audience). We need to realize that the needs of the agricultural sector are different than the need of the fisheries or the tourism sectors.

- We can provide a tool but not a cook recipe. This tool would help the end-users in their decision making, ideally leading them to better decisions than without taking into account climate information.

Edited by: P. Fabian and J. L. Santos

Reviewed by: two anonymous referees

\section{References}

Balbus, J. M. and Wilson, M. L.: Human Health and Global Climate change, Pew Center on Global Climate Change, 43 pp., 2001.

Barber, R. T. and Chavez, P.: Biological Consequences of El Niño, Science, 222, 1203-1210, 1983.

Berri, G. J. (Ed.): Impact of ENSO on the Hidric Resources of the American Continent and new Methodologies applied to the seasonal and interannual hydrological forecast, IRI Applications and Training Pilot Project, IRIP-CR-SF96/1, 114 pp., 1995.

CAF, Corporación Andina de Fomento: Las Lecciones de El Niño, Retos y propuestas para la Región Andina, ISBN 980-340-173-4, Volumen I: La región Andina, 235 pp; Volumen II: Bolivia, 280 pp; Volumen III: Colombia, 245 pp.; Volumen IV: Ecuador, 250 pp.; Volumen V: Peru, 293 pp.; Volumen VI: Venezuela, 248 pp., 2000.

Caviedes, C. N. and Fik, T. J.: Climate variability, climate change and fisheries, edited by: Glantz, M. H., Cambridge University Press, 356-374, 1992.

CEPAL, Comisión Económica para América Latina y el Caribe: Ecuador: Evaluación de los Efectos Socio Económicos del Fenómeno de El Niño en 1997-1998, LC/R.1822, 75 pp., 1998.

CEPAL, Comisión Económica para América Latina y el Caribe: Los Desastres Naturales de 1982-1983 en Bolivia, Ecuador y Perú, E/CEPAL/G.1274, 226 pp., 1983.

FAO, The Food and Agriculture Organization of the United Nations: FAO Global Information and Early Warning System on Food and Agriculture, available at: http://www.fao.org/giews/english/ index.htm, 2005.

Flores, M. J.: Incidencia de los Fenómenos "El Niño" en la Extracción de Recursos Pesqueros Marinos de la Pesquería Peruana en el Periodo 1950-1987, Memorias del Simposium Internacional de los Recursos Vivos en las Pesquerías del Pacífico Sudeste. Comisión Permanente del Pacífico Sur., 467-476, 1989.
Holmgren, M., Stapp, P., Dickman, C. R., Gracia, C., Graham, S., Gutiérrez, J. R., Hice, C., Jaksic, F., Kelt, D. A., Letnic, M., Lima, M., López, B. C., Meserve, P. L., Milstead, W. B., Polis, G. A., Previtali, M. A., Richter, M., Sabaté, S., and Squeo, F. A.: A synthesis of ENSO effects on drylands in Australia, North America and South America, Adv. Geosci., 6, 69-72, 2006.

IPCC: Climate Change 2001: Synthesis Report, in: Contribution of Working Groups I, II, and III to the Third Assessment Report of the Intergovernmental Panel on Climate Change, edited by: Watson, R. T., Albritton, D. L., Barker, T., Bashmakov, I. A., Canciani, O., Christ, R., Cubasch, U., Davidson, O., Gitay, H., Griggs, D., Halsnaes, K., Houghton, J., House, J., Kindzewicz, Z., Lal, M., Leary, N., Magadza, C., McCathy, J. J, Mitchell, J. F. B., Moreira, J.R., Munasinghe, M., Noble, I., Pachauri, R., Pittock, B., Prather, M., Riches, R. G., Robinson, J. B., Sathaye, J., Schneider, S., Scholes, R., Stocker, T., Sundararaman, N., Swart, R., Taniguchi, T., and Zhou, D., Cambridge University Press, Cambridge, UK and New York, USA, 397 pp., 2001

Macharé, J. and Ortlieb, L.: Records of El Niño phenomena and ENSO events in South America. Bulletin de LÍnstitut Francais DÉtudes Andines, ISSN 0303-7495, 406 pp., 1993.

Meek, E. and Aldana, H. (Eds.): Experiences on the Prevention and Reconstruction of areas affected by the Presence of El Niño in Agriculture, Instituto InterAmericano de Cooperación para la Agriculture, IICA, 199 pp., 1998.

NOAA: National Oceanic and Atmospheric Administration, News Releases, available at: http://www.publicaffairs.noaa.gov/ releases2002/july02/noaa02089.html, 2002.

RIBEN: Monitoring Network on the Biological Impacts of ERNSO, available at: http://www.concytec.gob.pe/investigacion/biologia/ riben/iriben.htm, 2005.

Santos, J. L.: Extreme Climate Events and Socio-Economic Value of Seasonal Prediction, Proceedings of the Fourth APCN Working Group Meeting, Climate Prediction Division, Korea Meteorological Administration, 8-11, 2004.

Santos, J. L.: El Niño and La Niña: A Climate Oscillation, on: El Niño Event in Ecuador: From Disaster to Prevention, Comitato Internazionale per lo Sviluppo dei Popoli, 205 pp., 1999.

Tarazona, J., Arntz, W., and Castillo, E. (Eds.): El Niño in Latin America: Biological and Social Impacts, Alfred Wegener Institute, ISBN 9972-50-015-2, 423 pp., 2001.

Tarazona, J. and Castillo, E. (Eds.): El Niño 1997-98 and its impact on the Marine and Terrestrial Ecosystems, Revista Peruana de Biología, ISSN 1561-0837, 186 pp., 1999.

WHO: Climate Change and Human Health - Risks and Responses, Summary, ISBN 92-4-159081-5, 37 pp., 2003.

WMO: The Global Climate System Review, June 1996-December 2001, World Climate Data and Monitoring Programme, WMONo. 950, 28-29, 2003.

WMO: Climate information and Prediction Systems and agrometeorological applications for the Andean Countries, WMO/TD No. 1234, 221 pp., 2004. 